\title{
Engineering and Empire Development
}

$\mathrm{I}^{\mathrm{N}}$ his capacity as the head of the oldest and most famous engineering institution in the world, the president of the Institution of Civil Engineers occupies a position of undisputed authority, the realization of the character of which has led successive presidents to deliver addresses which, taken collectively, constitute a history of engineering. Some of these addresses have been confined to the particular branch to which the speaker has devoted his life, others contain surveys of many branches, while others again contain valuable autobiographical or biographical sketches. Few of the addresses are not without permanent interest, and some thirty years ago Engineering referred to the whole as being to the Institution " $a$ heirloom left it by the many great men who helped so devotedly to build up the position of our Empire".

The addresses of Telford and Walker, who occupied the president's chair from 1820 until 1845 , were short and were mainly concerned with the activities of the Institution itself, and the prototypes of the modern presidential address are those of Sir John Rennie in 1846 and 1847, and of Joshua Field, in the two succeeding years. Rennie's first address runs to more than one hundred pages in the Proceedings. It dealt with a multiplicity of things including bridges, tunnels, harbours, gas, water, railways, steam carriages, steam navigation and telegraphy and even touched upon mineralogy, geology and meteorology. It reviewed the vast development of engineering from the time Smeaton began work on the Eddystone Lighthouse down to 1846, a period of ninety years. Twenty years later, Sir John Fowler spoke of this address as "a history of engineering and a manual of engineering science". A still longer address was that of Sir William White who, however, confined himself entirely to the progress of naval architecture and marine engineering during the preceding half century, a field in which he himself had played a part second to none. But whether the addresses have been long or short, whether they have dealt with wide surveys or a single subject, they are nearly all excellent reading, and over and over again reference has been made to the many great works designed and carried out by British engineers both at home and abroad, whether in foreign countries or in the British Dominions. There were, therefore, numerous precedents for Sir Alexander Gibb's choice of the title "Engineering and Empire Development", for his address delivered on November 3.
Sir Alexander himself, it is almost unnecessary to say, has had experience in many branches of engineering. Born in 1872, he was a student of University College, London, and then a pupil under Sir John Wolfe Barry and H. M. Brunel. Between 1905 and 1917 he was engaged on the construction of the New Alexandra Dock at Newport, Monmouthshire and the Royal Naval Dockyard at Rosyth, and during the Great War was chief engineer for port construction for the British Armies in France and Belgium. As senior member of Sir Alexander Gibb and Partners, he has recently been responsible, not only for the Kin. cardine Bridge but also for the great Galloway hydro-electric scheme in south-west Scotland. Unlike many of his predecessors at the Institution of Civil Engineers, his principal work has been done at home, but in choosing the subject of his address, he was inspired partly by the address of Rennie and partly by the opportunity he had had of inspecting the great engineering works in the Dominions and Colonies, which in the last ninety years have wrought a change in conditions overseas similar to those wrought at home in the ninety years covered by Rennie's address.

The world before Smeaton's time, Sir Alexander said, had apparently stood still; suddenly there arose a body of great engineers who, in a few years, created a new era. This, he suggested, was a natural evolution from the more abstract discoveries of science due to such as Copernicus, Galileo, Kepler and Newton. H. R. Palmer, actually the first member of the Institution, had said that "the Philosopher searches into nature and discovers her laws and promulgates the principles upon which she acts. The Engineer receives those principles and adapts them to our circumstances". From the outset, engineers thus looked upon themselves as the practical exponents, for the ordinary use of mankind, of the scientific knowledge won by men of science and mathematicians. The basis and justification of the existence of the engineer, and his contribution to civilization, exist in the fact that the application of science to practical use is in fact engineering. The engineer of Rennie's time was of the type visualized by $H$. R. Palmer, and it is the same type of man who in the ninety years since 1846 has changed the face of the whole world and created the British Empire.

Dealing in turn with canals, roads, bridges, railways, ships, ports, transport; agriculture, irrigation, water-supply, sanitation, etc., Sir Alexander 
referred to such achievements as the canals which make it possible for ocean-going steamers to penetrate half-way across the continent of America, the $1,000,000$ miles of roads which serve the Empire, the 12,064-ft. long Lower Zambezi Bridge, one of the longest bridges in the world, the railways of Canada, India and Australia, the transoceanic trade in foodstuffs and the developments of ports. It is of interest to note that Smeaton's old chart of the Clyde showed a depth of 42 inches at high tide near a point where the Queen Mary was launched in 1934. Striking effects have been achieved by irrigation. It was after the famine of 1865-67 that irrigation was started in India on modern lines. Famines do not now occur in India ; shortage and scarcity exist at times, but the possibility of areas of the size and population of Great Britain being left without food owing to the failure of a capricious monsoon has long since been ended.

Whatever has been accomplished, however, "the opportunites of the future," said Sir Alexander, "are vastly greater than any that the past has offered, but frankly, I look with anxiety on the years to come. The machine ... sometimes seems to be taking control. Inventions and developments succeed one another with bewildering speed, and there seems, unfortunately, to be no limit to the possible results of uncontrolled and misapplied ingenuity. In such circumstances no one can say where Engineering may lead us or what limit there is to the power of the engineer. One thing is certain, and that is that there must be control".

Finally, Sir Alexander appealed for more cooperation between engineers themselves, for the subordination of personal and independent views and feelings to a common policy. "I would like it to be possible for one broad policy to inspire and guide all classes of engineer. I would hope that in time there would arise a body of engineering opinion so weighty, so authoritative, so sure, so sane, that it would prevent waste of energy and misplaced enterprise, and would inevitably command attention in the politics and administration and life of our country and Empire."

\section{Soil Drift in South Australia}

$\mathrm{T}^{\mathrm{H}}$ $E$ advances being made by deserts into areas occupied by man, sand drift, and desiccation, are problems which have awakened interest in several parts of the world. At the present time they are under consideration in the Middle West of the United States of America, in West Africa and in South Australia.

Under the auspices of the Council for Scientific and Industrial Research of the Commonwealth of Australia an important monograph (Pamphlet No. 64, Melbourne, 1936) on this subject entitled "Soil Drift in the Arid Pastoral Areas of South Australia" by Mr. F. N. Ratcliffe embodies the researches carried out by the author into this important matter. The history of the investigations are given in a foreword. During the year 1935, the minister in charge of the Council (Senator, the Hon. A. J. McLachlan) asked that consideration should be given to the possibility of undertaking any action to combat drift of soil in the arid and semi-arid parts of Australia. Mr. Ratcliffe, an officer of the Council, was deputed to under. take investigations in typical areas such as the northern portions of South Australia. It is stated that the publication of the report must not be taken to mean that the opinions expressed in it necessarily represent the considered views of the Council.
The problem of soil drift in Australia, says the author, is not, of course, confined to the area dealt with in the report. In order to shorten the period given to the investigations undertaken, the work was confined to the pastoral areas of South Australia. In other regions vegetations differing in type from, and in many ways more complex than, those described in the report would have had to be studied. On the whole, it is considered very unlikely that the problem in, say, western New South Wales would differ essentially from that in South Australia, although the details of the picture might not be quite the same.

The problem of soil drift and the deterioration of the pastoral country is a factor of very considerable importance to Australia's future, as is the case in certain other parts of the world. It is therefore, as the author states, very desirable, if not essential, that its nature and the difficulties which it presents should be properly appreciated by laymen and administrators as well as by scientific workers. Since the laws upon which a country is governed are the work of the administration, the burden of responsibility for a failure to recognize and then deal with a state of affairs often aggravated if not produced by man himself rests with the administrators. Mr. Ratcliffe presents a very clear picture of the 